\title{
COGNITIVE BEHAVIOUR THERAPY UNTUK PENINGKATAN HARGA DIRI REMAJA PUTRA DI PANTI ASUHAN “M” KLATEN
}

\author{
Dian Hapsari ${ }^{1}$, Kamsih Astuti $^{2}$ dan Sriningsih ${ }^{3}$ \\ ${ }^{123}$ Fakultas Psikologi, Universitas Mercu Buana Yogyakarta \\ dianhapsari@gmail.com
}

\begin{abstract}
Tujuan dari penelitian ini adalah untuk mengetahui efek dari Cognitive Behavior Therapy (CBT) untuk meningkatkan efikasi diri anak-anak muda di panti asuhan M Klaten. Pemberian program ini berdasarkan teori dari Driffin, dkk. (Matthys \& Lochman, 2010) dalam bentuk perilaku manajemen, modeling, ketrampilan pemecahan masalah, restructuring dan relaksasi kognitif. Subjek berjumlah 10 anak muda laki-laki yang tinggal di panti asuhan dan memiliki self estem yang rendah berdasarkan pada skor dari Coopersmith Self Esteem Inventory (CSEI). Hasil dari hipotesis pertama dari penelitian ini menunjukkan bahwa tidak ada perbedaan self esteem antara $\mathrm{KE}$ dan KK ( $\mathrm{Z}=-0.329$; $\mathrm{p}>0.05)$ dan hipotesis kedua pada penelitian ini terbukti bahwa hasil dari analisis menunjukkan perbedaan self esteem antara KE dan KK sebelum dan sesudah diberikan CBT $(Z=-2.070 ; p>0.05)$.
\end{abstract}

Kata kunci: self esteem, cognitive behavior therapy (CBT)

\section{COGNITIVE BEHAVIOUR THERAPY FOR MALE ORPHAN ADOLESCENT SELF-ESTEEM IMPROVEMENT IN ORPHANAGE "M" KLATEN}

\author{
Dian Hapsari ${ }^{1}$, Kamsih Astuti $^{2}$ dan Sriningsih ${ }^{3}$ \\ ${ }^{123}$ Faculty of Psychology, Mercu Buana Yogyakarta University \\ dianhapsari@gmail.com
}

\begin{abstract}
The objective of this research is to determine the effect of Cognitive Behaviour Therapy (CBT) to increase male orphan adolescent self-esteem improvement in orphanage "M" klaten . The given program refers to the advanced theory by Griffin, et al (Matthys \& Lochman, 2010) in the form of behavioral management, modeling, problem solving skills, cognitive restructuring and relaxation. The subjects numbered 10 young men who live in the orphanage and have a low selfesteem based on the score of Coopersmith Self Esteem Inventory (CSEI). Results of the first hypothesis of this study shows that there is no difference in self-esteem between $\mathrm{KE}$ and $\mathrm{KK}(\mathrm{Z}=$ $0.329 ; p>0.05)$ and the second hypotheses of the study proves that results of the analysis shows no difference in KE self-esteem before and after given CBT on $\mathrm{KE}(Z=-2.070 ; \mathrm{p}<0.05)$.
\end{abstract}

Keywords: Self-Esteem, Cognitive Behaviour Therapy (CBT) 


\section{PENDAHULUAN}

Panti asuhan adalah tempat untuk memelihara dan merawat anak yatim, piatu dan yatim piatu. Sebuah panti asuhan merupakan lembaga yang ditujukan untuk perawatan anak yatim yaitu anak yang orangtua biologisnya meninggal atau tidak mampu atau tidak mau merawat mereka (Unicef.org, 2014). Lebih lanjut disebutkan dalam website Kementerian Sosial RI. bahwa Panti Sosial Asuhan Anak (PSAA) merupakan panti sosial yang mempunyai tugas memberikan bimbingan dan pelayanan bagi anak yatim, piatu, dan yatim piatu yang kurang mampu, terlantar agar potensi dan kapasitas belajarnya pulih kembali dan dapat berkembang secara wajar (Kemsos.go.id, 2014). Jadi panti asuhan merupakan tempat yang memberikan perawatan, perumahan dan pendidikan (Wikipedia.org, 2014).

Kekurangan mendasar yang ditemukan di panti asuhan adalah ketiadaan peran orangtua kandung bagi proses perkembangan kepribadian individu. Meskipun peran ini diambil alih oleh pengasuh panti asuhan, kasih sayang yang diberikan oleh orangtua merupakan modal yang baik bagi perkembangan kepribadian individu, khususnya dalam perkembangan anak dan remaja. Remaja yang dibesarkan dengan kehangatan dan pola asuh positif akan merasa diterima sebagai seseorang yang memiliki kemampuan dan berguna (Berk, 2003). Perkembangan kepribadian remaja memunyai arti yang khusus, dikatakan demikian karena remaja tidak memiliki tempat yang jelas dalam rangkaian proses perkembangan seseorang (Mönks, Knoers, \& Haditono, 2009). Masa remaja dikatakan sebagai masa transisi, periode peralihan, perubahan, usia bermasalah, masa pencarian identitas, usia yang menimbulkan ketakutan, masa yang tidak realistik dan ambang masa dewasa, karena belum memunyai pegangan. Pada sisi yang lain, kepribadian remaja masih belum terbentuk stabil, masih dalam proses pembentukan pola kepribadian, sehingga belum diperoleh suatu gambaran yang jelas tentang dirinya dan remaja belum bisa menjalankan peran yang harus diembannya (Hurlock, 2007).

Menurut Havighurst (Panuju \& Umami, 2009), tugas perkembangan masa remaja difokuskan pada upaya untuk mencapai kemampuan bersikap dan berperilaku sebagai orang dewasa bertanggungjawab dalam lingkungannya sebagai fondasi agar remaja dapat hidup bermasyarakat. Oleh karena itu, jika remaja berhasil melalui tugas perkembangan ini dengan sukses, akan menghadirkan fase bahagia dan membawa keberhasilan dalam pelaksanaan tugas-tugas perkembangan berikutnya. Akan tetapi jika remaja gagal melalui tugas perkembangan ini maka akan timbul rasa tidak bahagia dan kesulitan dalam menjalankan tugas-tugas perkembangan berikutnya. Remaja yang tinggal di panti asuhan sejak kecil meskipun 
mendapatkan kasih sayang dan perhatian cukup dari pihak lembaga, tetapi hal itu tidak cukup. Para pengasuh di panti asuhan memiliki keterbatasan untuk dapat memerhatikan seluruh remaja yang tinggal di panti asuhan. Para pengasuh di panti asuhan mengalami kesulitan apabila harus memerhatikan setiap aspek perkembangan masing-masing remaja secara adil. Perhatian yang bisa diberikan biasanya sebatas perkembangan fisik, seperti mencukupi kebutuhan makan, pakaian, dan keperluan sekolah. Apalagi keberadaan remaja di panti asuhan, biasanya bukan atas dasar pilihan mereka sendiri, bahkan seringkali remaja merasa malu terhadap diri mereka sendiri karena keberadaan mereka di panti asuhan. Kondisi tidak adanya pengakuan keberadaan remaja panti asuhan, terutama dari orangtua, dapat menyebabkan keterasingan dalam kepribadian mereka. Remaja akan merasa bahwa dirinya dipisahkan dan dibuang (Supraktiknya, 2003).

Pengalaman-pengalamanyang diperoleh remaja selama tinggal di panti asuhan akan berpengaruh terhadap penilaian mengenai dirinya. Penilaian remaja di panti asuhan terhadap dirinya sendiri terbentuk bersama dengan pergaulan teman seasramanya, ketika melakukan kegiatan bersama-sama di panti asuhan. Sebagian remaja panti dapat memunculkan perilaku-perilaku negatif, seperti perilaku agresif, mudah tersinggung, atau justru menjadi pendiam, yang berujung pada kekurangmampuan remaja untuk menghargai dirinya sendiri karena pergolakan batin sebagai remaja panti asuhan. Dengan kata lain remaja di panti asuhan berkemungkinan memiliki harga diri rendah.

Harga diri merupakan penilaian diri sendiri yang diperoleh dari hasil interaksi individu dengan lingkungannya, penghargaan dan penerimaan dari orang lain (Chaplin, 2009). Menurut Tambunan (2001), harga diri mengandung suatu hasil penilaian individu terhadap dirinya yang diungkap dalam sikapsikap yang dapat bersifat positif dan negatif. Dalam konteks kesehatan mental, harga diri memiliki peran sangat penting. Individu yang memiliki harga diri tinggi berarti memandang dirinya secara positif. Individu dengan harga diri tinggi sadar akan kelebihan-kelebihan yang dimilikinya dan memandang kelebihankelebihan tersebut lebih penting daripada kelemahannya. Sebaliknya, individu dengan harga diri rendah cenderung memandang dirinya secara negatif dan terfokus pada kelemahan dirinya (Baron \& Byrne, 2004). Harga diri yang tinggi, akan memampukan remaja untuk mengukir prestasi, dengan kata lain bila remaja mampu memahami diri dan potensi mereka, memiliki motivasi untuk mengoptimalkan potensi atau dengan kata lain harga dirinya tinggi, maka hal itu akan berkorelasi positif dengan peningkatan prestasi belajarnya di sekolah.

Pembentukan harga diri remaja dipengaruhi oleh pengalaman, pola asuh, dan lingkungan sosial ekonomi (Burns, 1998). 
Lingkungan memberi dampak besar bagi remaja melalui hubungan yang baik antara remaja dengan orangtua, teman sebaya, dan lingkungan sekitar, sehingga menumbuhkan rasa aman dan nyaman dalam penerimaan sosial dan akhirnya membentuk harga diri yang tinggi (Burns, 1998). Gandaputra (2009) meneliti gambaran harga diri remaja yang tinggal di panti asuhan, hasilnya menunjukkan remaja yang tinggal di panti asuhan lebih banyak yang memiliki harga diri rendah.

Berdasarkan hasil wawancara peneliti dengan 5 orang remaja putra di panti asuhan $M$, diperoleh informasi sebagai berikut: $A B$ (16 tahun) merasa malu dengan status "anak panti asuhan", merasa "diabaikan", merasa "minder" terhadap remaja lain yang tinggal bersama dengan orangtua kandungnya, merasa tidak percaya diri dengan teman-teman sekolahnya, dan merasa iri kepada temantemannya yang tinggal bersama orangtua kandungnya. Demikian juga dengan KI (15 tahun) dan AS (14 tahun) sebagai anak panti asuhan mereka minder dalam pergaulan karena merasa malu sebagai anak yang hidup di panti asuhan sehingga lebih memilih untuk bergaul dengan sesama teman yang tinggal bersama di panti asuhan ataupun membatasi pergaulan mereka hanya bergaul dengan teman-teman yang juga berasal dari kalangan kurang mampu agar tidak malu.

Anak di panti asuhan merasa kesulitan bergaul dengan anak yang dianggap lebih baik darinya yang hidup di rumah sendiri bersama kedua orangtuanya karena merasa mereka berbeda dibandingkan anak-anak lain yang memunyai keluarga, tinggal di rumah sendiri dan hidup berkecukupan. Anak-anak panti asuhan mengatakan bahwa mereka hanyalah anak panti asuhan yang tidak memiliki orangtua dan kehidupannya menderita. Hasil waancara tersebut diperkuat dengan observasi yang peneliti lakukan di panti asuhan bahwa ke lima anak tersebut terlihat lebih banyak menyendiri tidak ikut bergabung bersama teman-temannya, sering melamun, tidak bisa mengemukakan pendapat, ketika ditunjuk untuk tampil di depan umum mereka tidak bersedia untuk tampil, mudah merasa puas dengan apa yang diperoleh dan mudah menyerah.

Permasalahan harga diri yang dialami remaja dapat memengaruhi cara remaja bergaul, bersikap serta berinteraksi sosial dengan lingkungan sekitarnya. Remaja yang memiliki harga diri rendah akan menampilkan tingkah laku mudah menyerah dan putus asa bila menemui kegagalan, kurang bersemangat untuk mencapai cita-citanya, kurang mampu membangun hubungan dengan orang lain serta kurang percaya diri. Harga diri yang rendah bisa berdampak pada perilaku negatif, seperti motivasi berprestasi dan prestasi akademik yang rendah (Wahyuni, 2010), kecenderungan depresi (Aditomo, 2004), hingga penyalahgunaan narkotika dan obat-obatan berbahaya (Pradana, 2008). 
Dengan demikian harga diri yang rendah berkaitan dengan berbagai dampak negatif sehingga diperlukan suatu intervensi yang efektif untuk meningkatkan harga diri. Beberapa intervensi yang telah dilakukan untuk meningkatkan harga diri, antara lain: penerapan konseling realita untuk meningkatkan harga diri siswa(Sulistyowati \&Warsito, 2010), teknik self instruction untuk meningkatkan harga diri (Larasati, 2012) dan teknik cognitive behavior therapy untuk menurunkan distres psikologis dan meningkatkan harga diri remaja putri penderita obesitas. Cognitive behavior therapy (CBT) merupakan salah satu teknik terapi yang terbukti efektif untuk meningkatkan harga diri. CBT digunakan dalam penelitian ini karena melihat proses pembentukan harga diri rendah yang terjadi pada remaja putra di panti asuhan dimulai dari adanya pengalaman negatif dalam hidup. Keyakinan mengenai diri sendiri dan dunia seringkali merupakan kesimpulan terhadap pengalaman-pengalaman yang telah dilalui individu. Apabila individu banyak mengalami pengalaman negatif di masa awal hidupnya yaitu saat anak-anak ataupun remaja, maka kemungkinan besar individu tersebut akan mengembangkan keyakinan diri yang negatif.

Kondisi yang terjadi pada anak di panti asuhan yaitu kurang mendapat perhatian dan pujian, selain itu anak yang tinggal di panti asuhan cenderung menarik diri dari pergaulan di lingkungannya, pendiam dan pemalu karena sering mendapat hinaan dan dikucilkan dalam pergaulan. Berdasarkan penjelasan diatas, diperlukan sebuah penanganan yang tepat dalam upaya meningkatkan harga diri remaja dengan pendekatan CBT menuntut remaja untuk menyadari proses yang membuat keyakinan negatif dalam diri secara berkelanjutan, termasuk cara pemrosesan informasi serta mempelajari cara mengatasi hal ini.

Dari berbagai teknik yang ada peneliti tertarik menggunakan CBT karena mengusung restrukturasi kognitif. Pemilihan ini didasari oleh latar belakang bahwa harga diri merupakan sebuah evaluasi diri. Dan memiliki esensi yang terletak pada keyakinan dasar negatif mengenai dirinya keyakinan ini melibatkan kognisi individu yang kemudian berlanjut pada sebuah perilaku dimana individu dengan harga diri rendah cenderung menarik diri dari lingkungan. Oleh karena itu peneliti memandang bahwa intervensi CBT lebih sesuai untuk meningkatkan harga diri.

CBT dapat digunakan dalam terapi individual maupun kelompok, serta menjadi satu teknik yang sering diadaptasi untuk aplikasi self-help. CBT bertujuan untuk memecahkan masalah tentang disfungsional emosi, perilaku dan kognisi melalui prosedur yang berorientasi pada tujuan. Metode ini dikenal dengan tahapan-tahapannya yang sistematis, berorientasi tujuan, dan bisa cukup leluasa dikombinasyikan dengan metode lain 
untuk mewujudkan proses psikoterapi yang integratif (psikologi.ugm.ac.id 2014).

Semua kejadian yang dialami berlaku sebagai stimulus yang dapat dipersepsi secara positif maupun negatif. Isi pikiran yang positif akan memengaruhi perasaan dan perilaku menjadi positif, sedangkan isi pikiran yang negatif dapat mengakibatkan gangguan emosi (perasaan). Menurut konsep dasar ini, emosi akan memengaruhi perilaku, baik secara positif atau negatif. Jadi salah satu upaya untuk menigkatkan harga diri menuju ke arah positif adalah dengan Cognitive Behavior Therapy, yaitu suatu bentuk terapi modifikasi fungsi pikiran, perasaan, dan perbuatan (perilaku), melalui fungsi kognitif dalam menganalisis, memutuskan, bertanya, berkehendak, dan memutuskan kembali. Dengan mengubah status pikiran dan perasaan, individu dapat mengubah perilakunya dari negatif menjadi positif (Sudiyanto, 2007).

Individu dengan harga diri rendah menilai banyak hal negatif mengenai dirinya sendiri. Harga diri rendah adalah perasaan tidak berharga, tidak berarti dan rendah diri yang berkepanjangan akibat evaluasi negatif terhadap diri sendiri atau kemampuan diri. Adanya perasaan hilang kepercayaan diri, merasa gagal karena tidak mampu mencapai keinginan sesuai diri ideal akan menyebabkan harga diri yang rendah (Keliat, 1999). Dengan dilakukannya terapi CBT, diharapkan dapat mengubah pikiran negatif klien menjadi pikiran yang positif, sehingga dapat meningkatkan harga diri. Dengan demikian berdasarkan hasil-hasil penelitian terdahulu dapat diketahui bahwa CBT efektif untuk meningkatkan harga diri pada berbagai peserta. Penelitian ini akan melihat efektifitas CBT untuk peningkatan harga diri remaja putra di panti asuhan "M" Klaten.

Berdasarkan tinjauan pustaka dan kerangka berfikir dalam penelitian ini, maka dapat diajukan hipotesis sebagai berikut:

1. Ada perbedaan harga diri antara kelompok eksperimen dan kelompok kontrol. Harga diri kelompok eksperimen lebih tinggi dari pada kelompok kontrol

2. Ada perbedaan harga diri antara kelompok eksperimen sebelum mendapat CBT dengan setelah mendapat $\mathrm{CBT}$, setelah CBT harga diri peserta lebih tinggi dari pada sebelum CBT

\section{METODE}

Variabel-variabel yang digunakan dalam penelitian ini adalah sebagai berikut:

1. Variabel tergantung (dependent) adalah harga diri yaitu penilaian terhadap dirinya sendiri, penerimaan pada diri yang diekspresikan melalui perilaku dan sikapnya terhadap diri sendiri, yang bersifat positif maupun negatif yang menghasilkan perasaan berharga. Harga diri diukur dengan Skala Harga Diriadaptasi dari Coopersmith Self Esteem Inventory (CSEI) oleh Hidayat, 2011. 
Semakin tinggi skor yang diperoleh berarti semakin tinggi harga dirinyasebaliknya, skor yang rendah menunjukkan harga dirirendah.

2. Variabel bebas (independent) adalah perlakuan berupa intervensi cognitive behavior therapy (CBT) yaitu terapi untuk mengenali hubungan antara pikiran dan respon individu terhadap situasi yang menimbulkan masalah. Individu membantu dirinya sendiri untuk mengubah pikiran dan emosi yang salah menjadi respon perilaku positif. Modul CBT disusun berdasarkan teori yang dikembangkan oleh Griffin, dkk (Matthys \& Lochman, 2010) mencakup Behavioral management, modeling, Problem solving skill, Social problem solving, Cognitive restructuring dan Relaxation. CBT diselenggarakan dalam 1 hari yang terbagi atas 2 sesi.

Subjek dalam penelitian ini berjumlah 10 orang remaja putra yang tinggal di panti asuhan "M". Adapun kriteria subjek penelitian yaitu: remaja putra, tinggal menetap di panti asuhan " $M$ " Klaten dan memiliki harga diri rendah.Subjek penelitian dibagi menjadi 2 kelompok secara random, yaitu kelompok eksperimen dan kelompok kontrol. Kelompok eksperimen mendapat perlakukan berupa terapi CBT, sedangkan kelompok kontrol tidak mendapat perlakuan.

Penelitian ini menggunakan desain eksperimental, dengan desain pretest-posttest control group design (Gravetter \& Forzano, 2009). Penelitian ini menggunakan satu kelompok eksperiemen (KE) dan satu kelompok kontrol (KK) yang diberikan pretest sebelum perlakuan, kemudian diberikan posttest setelah perlakuan dan setelah itu follow up. Proses random assignmentdilakukan setelah pretest dengan cara mengacak peserta yang berada dalam kategori rendah dan sedang untuk menjadi KE dan KK.

Pada desain ini, tingkah laku diamati sebelum intervensi sebagai baseline pada KE dan KK kemudian pengamatan dilakukan kembali setelah intervensi dilakukan, lalu hasilnya dibandingkan.

Penelitian dengan desain ini ditujukan untuk melihat perubahan peserta sebelum dan sesudah intervensi diberikan. Kedua data dibandingkan untuk melihat apakah terjadi perubahan dalam diri peserta. Pengukuran data baseline dan data sesudah intervensi dilakukan secara kuantitatif dan kualitatif. Data kuantitatif diperoleh dengan melakukan pengukuran tingkat harga diri dengan CoopersmithHarga diriInventori.

Metode pengumpulan data menggunakan skala harga diri yang diadaptasi dari skala Harga Diri Copersmith oleh Hidayat, (2011). Indikator dari dimensi harga diri Coopersmith (Hidayat, 2011), meliputi power, virtue, significance dan competence.Skala ini terdiri dari 58 aitem menggunakan rating 2 poin "ya dan tidak". Dalam penyekoringannya, karena tes ini melibatkan dua pernyataan 
pilihan, "ya dan tidak", maka penilaiannya adalah nol dan satu. Skor maksimal dari skala ini adalah 50, karena terdapat 8 aitem poligraf yaitu aitem yang tidak dipertimbangkan dalam menyumbangkan skor total. Aitem-aitem poligraf yaitu aitem dengan nomor $6,13,20$, 27, 34, 41, 48 dan 55. Skala harga diri memiliki daya beda aitem berkisar antara 0,549 sampai 0,771, dengan koefisien reliabilitas sebesar $r=0,879$.

Analisis data menggunakan uji U Mann whitney untuk membandingkan gainedscore harga diri antara kelompok eksperimen dan kelompok kontrol. Kemudian pada kelompok eksperimen dilihat perbedaan skor pre test dan post testuji Wilcoxon untuk mengetahui ada tidaknya perbedaan skor harga diri antara sebelum subjek diberi CBT dengan setelah diberi CBT.

\section{HASIL DAN PEMBAHASAN}

Hasil analisis dengan U-Mann Whitney dari selisih skor pretest dan posttest (Gained skor) pada kelompok kontrol dan eksperimen diperoleh nilai $Z=0,329 ;(p>0,05)$. Dengan demikian tidak ada perbedaan harga diri antara KE dan KK

Hal ini dipengaruhi beberapa hal salah satunya adalah efek partisipan sebagai makhluk kognitif yang tinggi, subjek penelitian seringkali berusaha untuk mencari tahu apa yang mereka alami, apa yang mereka lakukan, dan respon apa yang akan diberikan sebelum berlangsungnya pemberian manipulasi.
Kondisi ini memungkinkan dapat terjadi karena kelompok kontrol berada di lingkungan yang sama dengan kelompok ekperimen dimana pada subjek kelompok kontrol dalam penelitian ini mengetahui bahwa dirinya dilibatkan dalam penelitian sebagai kelompok kontrol yang tidak mendapatkan terapi sehingga memunculkan motivasi dalam diri kelompok kontrol untuk lebih baik dari pada kelompok eksperimen yang mendapatkan terapi. Itulah sebabnya tidak terdapat perbedaan harga diri KE dan KK. Hal ini terungkap saat proses wawancara dengan salah satu subjek pada kelompok eksperimen yang menyampaikan teman-teman di panti asuhan terutama yang dilibatkan dalam penelitian yaitu kelompok dua (KK) sering mencari tahu apa yang mereka (KE) lakukan setiap pertemuan berlangsung.

Hasil analisis kuantitatif pada KE dilanjutkan dengan analisis Wilcoxon untuk melihat perubahan yang terjadi pada $\mathrm{KE}$ sebelum, sesudah dan follow up. Dari hasil penelitian yang dilakukan menunjukkan bahwa ada perbedaan antara harga diri sebelum dan sesudah diberikan Cognitive Behavior Therapy pada KE. Hal ini dilihat pada nilai $Z=-2,070$ $(p<0,05)$. Artinya ada perbedaan harga diri antara sebelum dan sesudah pemberian intervensi Cognitive Behavior Therapy secara statistik pada kelompok eksperimen. Kelima subjek menunjukkan adanya perubahan skor harga diri yang bermakna, tetapi semuanya berada pada kategori rendah. 
Kelompok eksperimen yang mendapatkan terapi menghasilkan skor harga diri yang meningkat. Mean pretest sebesar 24,80 dan mean posttes sebesar 26,00; sedangkan mean posttes 26,00 dan mean follow up 28,00; mean pretest adalah 24,80 dan mean follow up 28,00. Secara keseluruhan proses CBT berjalan dengan lancar. Kegiatan diskusi diakhir setiap sesi terapi sangat bermanfaat untuk mengetahui permasalahan subjek, apa yang subjek pikirkan dan bagaimana perasaan subjek saat mengalami permasalahan tersebut. Dengan diskusi juga membantu subjek untuk mengungkapkan semua emosi yang subjek rasakan selama ini dipendam. Subjek juga mampu berfikir positif, menahan emosi dan memikirkan tindakan yang dilakukan.

Cognitive Behavior Therapy efektif meningkatkan harga diri pada kelompok eksperimen. Terapi CBT yang diterapkan dalam penelitian ini menggunakan terapi kogntitif dari Griffin, dkk (Matthys \& Lochman, 2010) mencakup Problem solving skill, Behavioral management,Modeling, Cognitive restructuring dan Relaxation. Subjek akan diajak untuk memahami distorsi kognitif yang mereka alami sehingga memunculkan pola-pola pikir negatif, memahami emosi yang selama ini mereka rasakan saat ada kejadian atau konflik yang mereka alami. Jika remaja mampu mengontrol pikirannya maka tidak terjadi distorsi kognitif, sehingga tidak memengaruhi perasaannya.
Sesi Behavioral Management, metode yang digunakan $\mathrm{ABC}$, bertujuan untuk menemukan pola-pola unuik yang membuat perilaku maladaptif terus berulang oleh peserta. Setelah pola tersebut dapat ditemukan, peserta mampu mencari alternatif pilihan ketika kejadian yang dianggapnya mengancam terjadi, peserta sudah memaknai pengaruh dari pikirannya, emosi dan perilakunya serta menyadari akibat-akibat dari perilaku yang dilakukannya, maka peserta akan mencoba menemukan alternatif perilaku yang lebih adaptif. Kemudian mengenali pikiran-pikiran negatif dan respon yang biasa dilakukan dalam berbagai kejadian baik di sekolah, maupun di panti. Pada sesi ini, terapis akan mengajarkan suatu keterampilan baru untuk mengatasi pikiran, perasaan, perilaku otomatis yang dialami peserta pada kejadian-kejadian tertentu, (Wilson \& Branch, 2006).

Strategi kognitif behavioral merupakan intervensi yang paling tepat untuk meningkatkan harga diri individu, CBT dilakukan dengan menentang distorsi kognitif yang mengabaikan karakteristik positif, pikiran hanya berfokus dengan feedback negatif, sikap melebih-lebihkan pengalaman yang berkaitan ketidaknyamanan, ketidaksuksesan sebagai bukti kegagalan. Semua distorsi kognitif tersebut mengarah pada harga diri rendah, (Guindon, 2010). Ketika seseorang memiliki penilaian negatif terhadap dirinya sendiri, maka konsekuensi yang muncul adalah harga 
diri yang rendah, (Fannel, dalam Sarandria 2012).

Pada sesi $\mathrm{ABC}$ subjek ditantang untuk mampu mengubah pikiran negatif peserta sehingga muncul penilaian positif terhadap dirinya yang akan memunculkan harga diri tinggi. Proses $\mathrm{ABC}$ ini membuat subjek menyadari pikiran negatifnya yang menilai dirinya tidak baik, tidak sopan, pemalu dan kurang pergaulan dan subjek juga berfikir bahwa oranglain menganggap dirinya nakal, bodoh, pemalas, kurang bergaul dan pemalu. Namun setelah proses $A B C$ subjek menjadi paham apa yang subjek pikirkan dan rasakan akan memengaruhi perilakunya sehingga saat ini subjek memikirkan hal positif dari dirinya dan merubah penilaian negatifnya tentang orang lain terhadap dirinya yaitu subjek mulai memandang dirinya secara positif dengan memikirkan hal baik mengenai dirinya yaitu rajin, dermawan, solidaritas tingggi dan ramah, kemudian saat ini subjek juga telah merasa bagian dari kelompoknya, subjek mulai bercanda dengan orang lain agar dapat beradaptasi dan mulai berani bergaul dalam lingkungan. Orang-orang dengan harga diri tinggi lebih bahagia dan efektif dalam memenuhi tuntutan lingkungan dari pada orang yang berharga diri rendah. Orang dengan harga diri tinggi, akan menilai dirinya secara positif. Hal ini sudah terlihat pada subjek yang mulai menilai dirinya secara positif dengan melihat hal-hal positif yang subjek miliki. Sesi Modelling. Dalam ini peserta diminta untuk mengobservasi serta mengidentifikasi perilaku dari contoh film. Adapun judul cuplikan film yang ditampilkan ialah film yang berjudul Diary of a wimpy kid. Pada sesi ini setiap peserta dimintakan untuk memberikan tanggapan mengenai film yang diperlihatkan oleh terapis. Kemudian untuk menerapkan apa yang telah dilihat peserta dalam tayangan film, peserta diminta untuk role play. Setelah keseluruhan sesi selesai, terapis menyimpulkan seluruh kegiatan dalam terapi.

Melalui modeling secara langsung, remaja akan menangkap perilaku yang dianggap bermasalah dan bagaimana cara coping yang seharusnya dilakukan, hal ini dikarenakan melalui observasi secara langsung dapat memberikan makna, mudah diingat oleh subjek. Dengan melihat dan mempraktekkan secara langsung apa yang telah dilihat subjek dalam model yang ditampilkan dari tayangan film dapat memberikan contoh pada subjek untuk dapat berbuat seperti apa yang telah dilihat dan diperkuat melalui role play.

Jika subjek memiliki pemahaman serta keterampilan untuk mengatasi masalah dengan berbagai teknik coping maka ia akan dapat mengatasi penderitaan yang dihadapi. Setelah penayangan film dan role play subjek memiliki cara baru ketika mengalami situasi yang tidak menyenangkan seperti dihina oleh temanteman jika dulunya subjek lebih memilih diam, tidak memperdulikan dan terkadang ada juga subjek yang membalas hinaan itu yang berakibat pada terjadinya perkelahian. Akan 
tetapi setelah melihat role model dari film subjek memiliki cara yang lebih baik ketika menghadapi situasi yang yang tidak menyenangkan seperti dihina yaitu subjek bisa menyampaikan dengan tegas mengenai ketidak nyamanannnya dihina, subjek juga tidak mau terpengaruh dengan hinaan justru semakin berusaha untuk melakukan kegiatan positif untuk semakin membuat diri berkembang dari pada memikirkan hinaan orang lain terhadapnya. Orang yang memiliki harga diri tinggi cenderung membangun hubungan bersifat memelihara dari pada yang bersifat merugikan.

Sesi cognitive restructuring hal ini dikarenakan distorsi yang dialami oleh remaja yang memiliki harga diri rendah sebagai pemecahan masalahnya inilah dibutuhkan suatu cara agar proses kognitifnya lebih realistis dan adaptif. Perubahan suatu kognitif membutuhkan rekonstruksi kognitif. Terapi kognitif perilaku akan diberikan cara-cara dalam rekonstruksi kognitif. Subjek diajarkan untuk mengenali distorsi kognitif dengan pikiran yang lebih adaptif dan positif dalam melakukan interpretasi terhadap kejadiankejadian yang ada. Selain itu subjek diajarkan cara penyelesaian masalah yang lebih positif dibandingkan dengan menarik diri dari pergaulan. Melalui cognitive restructuring subjek diajak untuk menginterpretasi seluruh kejadian sehingga dapat lebih selektif dan mengubah cara pandang yang baru mengenai interpretasi permasalahan.
Perubahan cara pandang subjek dalam menginterpretasikan semua kejadian dapat membantu subjek lebih adaptif dimana subjek menjadi sadar bahwa selama ini pikiran subjek memengaruhi perasaan dan perilakunya sehingga menarik diri dari lingkungan dan kurang pergaulan. Saat ini subjek mulai memahami semua kejadian yang tidak menyenangkan dalam hidupnya.

Sesi relaxation ini yang bertujuan untuk mengontrol diri dan dapat meredam persoalan yang dialami pada keadaan yang tidak dimungkinkan oleh subjek. Terapis membantu peserta agar dapat menjadi pribadi yang tenang dan terampil dalam menanggapi persoalan, sesi ini diakhiri dengan pemberian tugas yang diberikan kepada peserta untuk melakukan relaksasi. Adapun tujuan dari sesi ini lebih meniti beratkan pada menurunkan tensi pikiran yang berlebihan.

Sebelum dimulai sesi, peserta terlebih dahulu diminta untuk mengambil posisi duduk yang dianggap nyaman dan tidak mudah terganggu, sesi ini digunakan relaksasi melalui safe place. Dalam proses ini pula terapis memasukan self instruction berupa kata-kata positif. Kalau kata-kata positif itu diterima akan mengubah penilaian terhadap diri yang tadinya memandang dirinya secara negatif dan terfokus pada kelemahan-kelemahannya lalu kemudian individu memiliki harga diri tinggi berarti memandang dirinya secara positif, sadar akan kelebihan-kelebihan yang dimilikinya dan memandang kelebihan tersebut lebih penting 
dari pada kelemahannya. Sebelumnya subjek lebih memandang dirinya negatif yaitu pemalu, tidak sopan, kurang bergaul, bodoh dan pemalas namun saat ini subjek mulai memandang dirinya positif yaitu subjek orang yang ramah, suka membantu teman, mudah bergaul, berani, optimis, pintar dan rajin beribadah. Relaksasi juga membuat subjek merasa nyaman, santai dan tenang.

Sesi Problem solving skill bertujuan untuk mengatasi berbagai kemungkinan permasalahan yang terjadi sehingga subjek dapat memahami cara yang tepat untuk mengatasinya dalam lingkungan sosial. Sesi problem solving skill diawali dengan identifikasi masalah, kemudian dilanjutkan dengan solusi yang biasa dilakukan oleh subjek kemudian efektifitas solusi dan alternatif solusi. Hal ini dikarenakan, subjek yang mengalami harga diri rendah kurang terampil dalam penyelesaian masalah yang dihadapinya. Sesi ini bertujuan untuk mencari berbagai solusi yang akan diambil dengan melihat konsekuensi-konsekuensi yang akan terjadi dalam proses penyelesaian permasalahan. Jika subjek dapat mengidentifikasi masalah dan bisa fokus untuk mengatasi dan meredakannya dengan menyusun alternatif solusi, maka akan mencari tantangan dan stimulus-stimulus berguna serta lebih ambisius. Apabila keterampilan dan pengetahuan yang subjek dapatkan dari proses terapi dapat terinternalisasi dengan baik maka subjek akan memandang dirinya secara positif, sadar akan kelebihan-kelebihan yang dimilikinya dan memandang kelebihan-kelebihan tersebut lebih penting daripada kelemahannya sehingga akan memampukan subjek untuk memahami diri dan potensi mereka, memiliki motivasi untuk mengoptimalkan potensi mereka dengan kata lain harga dirinya tinggi.

Subjek merasa telah memiliki alternatif solusi yang tepat dari pada sebelumnya, jika sebelumnya subjek saat dihina hanya bisa diam dan membiarkan saja dengan harapan orang yang menghinanya bisa berhenti menghina dirinya, saat ini subjek lebih memilih menyampaikan ketidaksukaannya secara tegas kepada orang yang menghinanya dan mempertanyakan alasan orang itu menghinanya dan membalikkan posisi orang yang menghinanya. Ada pula subjek yang malah memilih solusi dengan membalas menghina dan terlibat perkelahian ketika dihina karena setelah membalas subjek merasa lega, namun saat ini subjek merasa itu tidak menyelesaikan masalah justru malah menambah masalah sehingga subjek juga ingin berusaha tidak menyelesaikan masalah dengan perkelahian. Orang yang memiliki harga diri tinggi cenderung membangun hubungan bersifat memelihara dari pada yang bersifat merugikan.

Evaluasi secara keseluruhan dari hasil terapi Cognitive Behaviour Therapy subjek merasa bahwa cara berfikir bisa diubah menjadi positif, bisa menahan emosi, sebelum bertindak difikirkan akibatnya, berfikir positif 
ketika menghadapi suatu masalah agar masalah tidak berkembang, subjek juga merasa termotivasi untuk menjadi pribadi yang lebih baik, mampu menyadari kesalahan yang subjek perbuat. Ketika dilakukan follow up subjek telah mampu menilai dirinya secara positif dan berfikir posotif tentang dirinya dan oranglain dimana sebelumnya subjek lebih menilai diri negatif (bodoh, pemalas, pemalu, tidak baik, kurang bergaul dan nakal) namun saat ini subjek telah menilai dirinya lebih positif dengan melihat hal-hal yang positif dari dirinya (ramah, suka menolong, rajin, mudah beradaptasi dan optimis). Selain itu subjek juga mulai terlihat beradaptasi dan berinteraksi dengan lingkungan sekitar panti asuhan dimana sebelumnya subjek lebih banyak berinteraksi dengan sesama penghuni panti saja dari pada dengan oranglain di sekitar lingkungan panti asuhan.

Berdasarkan peningkatan skor harga diri pada pretest, posttest dan follow up pada kelompok eksperimen, perubahan masingmasing skor subjek yaitu; MH pada saat pretest skor harga diri sebesar 24, setelah diberi intervensi Cognitive Behaviour Therapy(posttest) skor harga diri menjadi 25 . Setelah dilakukan pengukuran kembali seminggu kemudian (follow up) skor harga diri menjadi 28.

Pada subjek MS pada saat pretest skor harga diri sebesar 32, setelah diberi intervensi Cognitive Behaviour Therapy(posttes) skor harga diri menjadi 33. Setelah dilakukan pengukuran kembali seminggu kemudian (follow up) skor harga diri menjadi 36. Kemudian pada subjek KR pada saat pretest skor harga diri sebesar 24, setelah diberi intervensi Cognitive Behaviour Therapy(posttest) skor harga diri menjadi 24. Setelah dilakukan pengukuran kembali seminggu kemudian (follow up) skor harga diri menjadi 26. Selanjutnya pada subjek AS pada saat pretest skor harga diri sebesar 18, setelah diberi intervensi Cognitive Behaviour Therapy(posttest) skor harga diri menjadi 20. Setelah dilakukan pengukuran kembali seminggu kemudian (follow up) skor harga diri menjadi 22. Terakhir subjek AL pada saat pretest skor harga diri sebesar 26, setelah diberi intervensi Cognitive Behaviour Therapy(posttes) skor harga diri menjadi 28. Setelah dilakukan pengukuran kembali seminggu kemudian (follow up) skor harga diri menjadi 28 .

Proses sebuah terapi membutuhkan waktu yang lebih lama untuk melihat efektivitas dari sebuah terapi, demikian juga dengan Cognitive Behaviour Therapy dilaksanakan dalam 12 sesi pertemuan, mayoritas klien berharap untuk menjalankan terapi antara enam sampai sepuluh sesi. Dalam praktiknya rata-rata klien bertahan dalam enam sampai delapan sesi terapi (Garfield dalam Sarandria 2012) . Namun dalam penelitian ini dilaksanakan selama satu hari dalam dua sesi sudah dapat meningkatkan harga diri, tetapi harga diri subjek tetap pada berada pada 
kategori rendah, pengukuran dilakukan selama dua minggu. Sehingga jika pelaksanaan terapi dapat dilaksanakan lebih lama akan terlihat peningkatan harga diri. Karena keterbatasan waktu subjek, maka intervensi dilakukan hanya dalam waktu satu hari. Hal ini disebabkan karena peneliti menyesuaikan terapi dengan jadwal kegiatan subjek yang saat ini masih bersekolah. Hal ini tidak sepenuhnya salah karena memikirkan kondisi situasional subjek juga merupakan hal yang penting. Namun pada penelitian yang mengukur efektifitas suatu treatment kepada subjek penelitian, ketidakteraturan jadwal pertemuan ini mengakibatkan kurangnya kontrol pada penelitian.

\section{KESIMPULAN}

Berdasarkan hasil analisis menunjukan bahwa tidak ada perbedaan harga diri antara $\mathrm{KE}$ dan $\mathrm{KK}(\mathrm{Z}=-0,329 ; \mathrm{p}>0,05)$. Hal ini dipengaruhi beberapa hal salah satunya adalah efek partisipan sebagai mahluk kognitif yang tinggi, subjek penelitian seringkali berusaha untuk mencari tahu apa yang akan mereka alami, apa yang mereka lakukan, dan respon apa yang akan diberikan sebelum berlangsungnya pemberian manipulasi.

Hal ini memungkinkan dapat terjadi karena kelompok kontrol berada di lingkungan yang sama dengan kelompok ekperimen dimana pada subjek kelompok kontrol dalam penelitian ini, mereka mengetahui bahwa dirinya dilibatkan dalam penelitian sebagai kelompok kontrol yang tidak mendapatkan terapi sehingga memunculkan motivasi dalam diri kelompok kontrol untuk lebih baik dari pada kelompok eksperimen yang mendapatkan terapi, sehingga tidak terdapat perbedaan harga diri KE dan KK.Hal ini terungkap saat proses wawancara dengan salah satu subjek pada kelompok eksperimen yang menyampaikan teman-teman di panti asuhan terutama yang dilibatkan dalam penelitian yaitu kelompok dua (KK) sering mencari tahu apa yang mereka (KE) lakukan setiap pertemuan berlangsung. Hipotesis satu dalam penelitian ini tidak terbukti yaitu tidak terdapat perbedaan harga diri antara kelompok kontrol dan kelompok eksperimen.

Hasil analisis terhadap KE menunjukkan ada perbedaan harga diri antara sebelum dan sesudah diberikan Cognitive Behavior Therapy pada $\mathrm{KE}(\mathrm{Z}=-2,070 ; \mathrm{p}<0,05)$. Artinya ada perbedaan harga diri antara sebelum dan sesudah pemberian intervensi Cognitive Behavior Therapy secara statistik pada kelompok eksperimen. Hasil penelitian menunjukkan ada peningkatan harga diri kelompok eksperimen antara pretest, posttest dan follow up. Kelompok eksperimen yang mendapatkan terapi menghasilkan skor harga diri yang meningkat (Mean pretest sebesar 24,80 dan mean posttes sebesar 26,00. sedangkan Mean Posttes 26,00 dan mean follow up 28,00. Mean pretest adalah 24,80 dan mean follow up 28,00). Hal ini berarti pada kelompok eksperimen ada peningkatan 
harga diri. Dengan demikian hipotesis dua pada penelitian ini terbukti. Intervensi Cognitive Behavior Therapy dapat meningkatkan harga diri remaja yang tinggal di panti asuhan.

Proses Cognitive Behavior Therapy, subjek menentang "pikiran otomatis"nya yang negatif menjadi pikiran positif, perubahan pikiran ini diikuti dengan emosi dan perilaku subjek. Hal ini diakui subjek cukup sulit untuk mengubah pikirannya, namun ada juga subjek yang sudah mampu mengubah pemikiran negatifnya diikuti dengan perubahan perasaan dan perilaku yang lebih positif. Kelima subjek menunjukkan adanya perubahan skor harga diri yang bermakna, tetapi semuanya berada pada kategori rendah.

\section{DAFTAR PUSTAKA}

Aditomo, A \& Retnowati, S. (2004). Perfeksionisme, harga diri, dan kecenderungan depresi pada remaja akhir. Jurnal Psikologi (1) 1 - 14.

Azwar, S. (2006), Metode penelitian, Yogyakarta: Pustaka Pelajar.

Arikunto, S. (2006). Prosedur Penelitian ; Suatu Pendekatan Praktik. Jakarta: Rineka Cipta.

Baron, R.A., \& Byrne, D. (2004). Social Psychology: Understanding Human Interaction. Boston: Allyn and Bacon,Inc.

Baker, LL \& Scart, K. (2002). Cognitive behavioral aproach to threating children \& adolescents with Conduct disorder. Ontarion: Childrens Mental Health
Berk, L E., (2003), Child Development, Boston : Pearson Education, Inc.

Beck, J. S. (2011). Cognitive Behavior Therapy : Basics and beyond. Second Edition. New York: Guilford Press.

Budiman, R. (2006). Harga diri pada anak panti asuhan tanah putih Semarang ditinjau dari persepsi terhadap penerimaan ibu asuh. Skripsi (tidak diterbitkan). Semarang: Fak. Psikologi Universitas Katholik Soegijapranata.

Burns, D D, M.D. (1998) Terapi Kognitif. Pendekatan baru bagi penanganan depresi, Jakarta: Erlangga.

Branden, N, (2002). The power of self-esteem. Florida : Health Communications, Inc.

Branden, N. (2009). Kiat jitu meningkatkan harga diri. Alih Bahasa. L. Noviatno \& A.R.H. Sitanggang. Jakarta : Pustaka Delapratesa.

Bruno, F.J. (2000). Menaklukan kesepian. Alih bahasa: L. Noviatno \& A.R.H Sitanggang. Jakarta: PT. Gramedia Pustaka Utama.

Chaplin, J. P. (2009). Kamus Lengkap Psikologi. Jakarta: Raja Grafindo Persada.

Dariuszky, G. (2004). Membangun harga diri. Bandung: CV. Pionir Jaya.

Duffy, K. G. \& Atwater, E. (2002). Psychology for living: Adjustment, growth, and behavior today (7th ed.). New Jersey: Pearson Education.

Erol, RY \& Orth, U. (2011). Self-Esteem Development From Age 14-30 Years: A Longitudinal Study. Washington: American Psychological Association.

Fennel, M. \& Jenkins, H.(2004). Low Harga diri. Dalam J. Bennet-Levy, G.Butler, 
M.Fennel et al (ed), Oxford Guide to behavioral experiments in Cognitive Therapy. Oxford: Oxford Medical Publ.

Frey, D \& Carlock, C. J. (2004). Enchancing harga diri. Indiana : Aclerated Development.

Gandaputra, A. (2009). Gambaran harga diri remaja yang Tinggal di panti asuhan. Jurnal Psikologi 7 (2).

Gravetter, F.J. \& Forzano, L.B. (2009). Statistic in Behavioral Science. Los Angeles: Sage Publications.

Guindon, M.H. (2010). Harga diri across the lifespan: Issues and interventions. New York: Rotledge.

Hidayat, E. (2011). Pengaruh Cognitive Behavior Therapy (CBT) dan Rational Emotive Behavior Therapy (REBT) terhadap klien perilaku kekerasan dan harga diri rendah di Rumah Sakit Marzoeki Mahdi Bogor. Manuskrip Penelitian. Politeknik Kesehatan Tasyikmalaya.

Hurlock E.B.

(2007).

Psikologi perkembangan: Suatu pendekatan sepanjang rentang kehidupan. Jakarta: Erlangga.

Kazdin, A. E.,Singel, T. \& Bass (1992). Cognitive problem-solving skill training and parent management training in thetreatment of anti social behavioral in children. Journal of Consulting and Clinical Psychology, 57, 733-747.

Kurniawan, W. (2014). Terapi kognitif perilakuan terhadap penurunangangguan perilaku menentang pada remaja di MTS $X$ Yogyakarta. Tesis (tidak diterbitkan). Yogyakarta. Universitas Mercu Buana Yogyakarta.

Keliat, B A. (1999). Proses keperawatan. Jakarta: EGC.
Kerlinger, F.N., dan Lee, H.B. (2000). Foundations of behavioral research (4th ed). Forth Worth: Harcourt Coledge Publisher.

Larasati, W.P. (2012). Meningkatkan harga diri melalui self instruction. Tesis. Jakarta: Fak. Psikologi Prodi Profesi, Universitas Indonesia.

Lim, L., Saulsman, L., \& Nathan, P. (2005). Improving self esteem. Perth: Centre for Clinical Intervention.

Marsalim, M. (2013). Strategi \& Intervensi Konseling. Jakarta Barat: Indeks.

Matthys, W \& Lochman, J. E. (2010). Oppositional defiant disorder and conduct disorder in childhood. Oxford: Jhon Wiley \& Sons.

Monks, F. J., Knoers \& Haditono, S R. (2009). Psikologi perkembangan: Pengantar dalam berbagai bagiannya. Yogyakarta: Gadjah Mada University Press.

Mruk, C.J. (2006). Harga diri" Research, theory, and practice ( $3^{\text {rd }}$ ed.). New York: Springer Publ. Co.

Nugrahawati, E N, \& Nugraha, G. (2011). Hubungan antara dukungan keluarga dengan "Harga diri" pada ODHA di Yayasan Akses Indonesia Tasyikmalaya.

Notoatmodjo. (2010). Metodologi penelitian kesehatan. Jakarta : Rineka Cipta

Oemarjoedi, K. (2003). Cognitive behavior therapy, edisi 1, Jakarta

Panuju P. \& Umami, I. (2009). Psikologi remaja. Yogyakarta: PT. Tiara Wacana.

Papalia, D. E, Olds, S.W., \& Feldman, R. D. (2008). Human development. (Tenth Edition). USA : McGraw-Hill. (2002). Psikologi Perkembangan. Jakarta : Kencana Prenada Media Group. 
Pradana, R. B H A. (2008). Hubungan antara Self-esteem dengan penyalahgunaan narkotika dan obat-obatan berbahaya pada siswa SMK Negeri 2 Malang. Skripsi, Malang: Jurusan Bimbingan Konseling dan Psikologi FIP Universitas Negeri Malang.

psikologi.ugm.ac.id. Lokakarya cognitive behavioral therapy bersama Dr. Theo Bouman.

http://psikologi.ugm.ac.id/berita.939/lok akarya-cognitive-behavioral-therapybersama-dr-theo-bouman.html diakses tanggal 3 desember 2014.

Reasoner, R. (2010). The True Meaning Of Self-Esteem. National Association for Self Esteem. http://www.self-esteemnase.org/what.php diakses tanggal 9 desember 2014.

Sarandria. (2012). Efektifitas Cognitive Behavioral Therapy (CBT) untuk Meningkatkan Harga diri pada Dewasa Muda. Tesis. Jakarta: Fakultas Psikologi. Program Magister Profesi Psikologi Universitas Indonesia.

Santrock, J. W. (2002). Life-span development: Perkembangan masa hidup (ed.5). Chusairi, A., \& Damanik, J. (Trans.). Jakarta: Erlangga.

Santrock, John W. (2003). Adolescence: Perkembangan remaja. Jakarta: Erlangga

Somers, J. (2007). Cognitive behavioral therapy: Core Information Document. Vancouver: CARMHA

Stallard, P. (2004). Think Good - Feel Good: A Cognitive Behavior Therapy, Workbook for Children and oung People. West Sussex: John Wiley \& Sons.
Steinberg, L. (1999). Adolescence (6th edition). New York: McGraw Hill.

Sudiyanto, A., (2007). Cognitive Behavior Therapy. "Bimbingan Teknis Psikoterapi”. Bagian Psikiatri FK UNS/ RS. Dr. Moewardi, Surakarta.

Sulistyowati, W., Warsito, H. (2010). Penerapan Konseling Realita Untuk Meningkatkan Harga Diri Siswa. Vol $11, \quad$ No $\quad \frac{\text { Vol }}{1,}$ (2010)http://ejournal.unesa.ac.id/index.p hp/jurnal ppb/article/view/5407 diakses 4 desember 2014.

Supraktiknya, A. (2003). Teori-Teori Psikodinamik (Klinis), Yogyajarta; Kanisius.

Susanti, T. (2013). Efektivitas Cognitive Behavioral Therapy In Group Untuk Meningkatkan Harga Diri Pada Remaja Putri Dengan Obesitas. Tesis. Yogyakarta: Universitas Gadjah Mada.

Tambunan, R. (2001). Harga Diri Remaja, Jakarta. [On-Line] FTP: www.e-psiko logi.com.

Wahyuni, A. (2010). Hubungan antara Harga diri, Motivasi Berprestasi dan Prestasi Belajar Siswa kelas VIII Paguyuban Peminat Seni Tradisi (PPST) SMP Negeri 4 Malang. Skripsi. Malang: Jurusan Bimbingan Konseling dan Psikologi Fakultas Ilmu Pendidikan Universitas Negeri Malang.

Willson, R \& Branch, R. (2006). Cognitive Behavioral Therapy for Dummies. West Sussex : Jhon Wiley \& Sons, Ltd

Zakiyah.(2014). Pengaruh Dan Efektifitas Cognitive Behavioral Therapy (CBT) Berbasis Komputer Terhadap Klien Cemas Dan Depresi. Tesis. E-Journal Widya Kesehatan Dan Lingkungan. 1 (1),

21-24. 